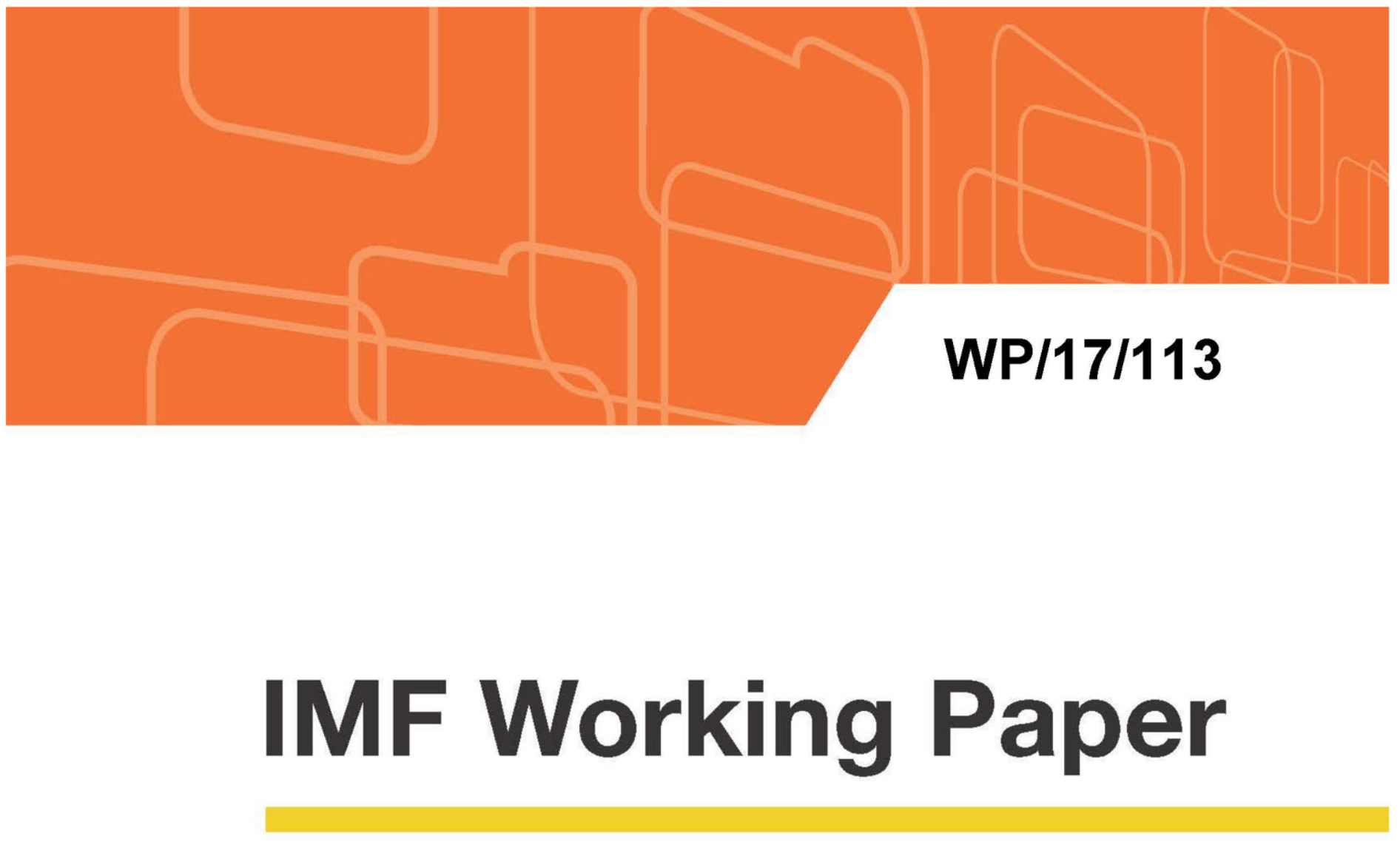

\title{
Collateral Reuse and Balance Sheet Space
}

\author{
by Manmohan Singh
}

IMF Working Papers describe research in progress by the author(s) and are published to elicit comments and to encourage debate. The views expressed in IMF Working Papers are those of the author(s) and do not necessarily represent the views of the IMF, its Executive Board, or IMF management.

$$
\text { I N T E R N A T I O N A L M O N E T A R Y F U N D }
$$




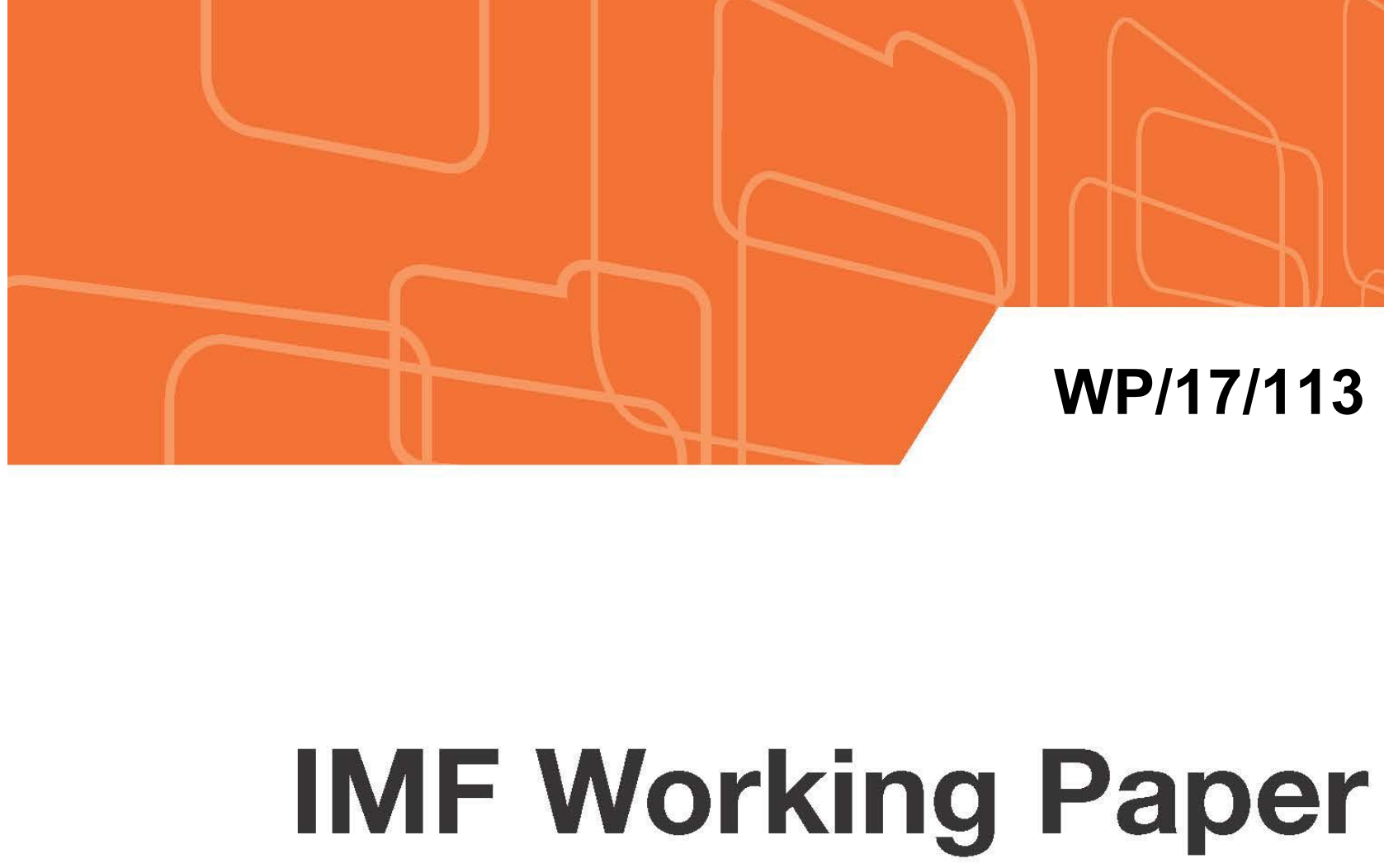

\section{Collateral Reuse and Balance Sheet Space}

by Manmohan Singh

IMF Working Papers describe research in progress by the author(s) and are published to elicit comments and to encourage debate. The views expressed in IMF Working Papers are those of the author(s) and do not necessarily represent the views of the IMF, its Executive Board, or IMF management.

$$
\text { I N T E R N A T I O N A L M O N E T A R Y F U N D }
$$




\title{
IMF Working Paper
}

Monetary and Capital Markets Department

Collateral Reuse and Balance Sheet Space

Prepared by Manmohan Singh ${ }^{1}$

Authorized for distribution by Gaston Gelos

April 2017

\section{IMF Working Papers describe research in progress by the author(s) and are published to elicit comments and to encourage debate. The views expressed in IMF Working Papers are those of the author(s) and do not necessarily represent the views of the IMF, its Executive Board, or IMF management.}

\begin{abstract}
Transactions on wholesale capital markets are often secured by marketable collateral. However, collateral needs balance sheet space to move within the financial system. Certain new regulations that constrain private sector bank balance sheets may have the effect of impeding collateral flows. This may have important consequences for monetary policy transmission, for short term money market functioning, and for market liquidity. In this context (and in contrast to the literature, which has focused mainly on the repo market), this paper analyzes securities-lending, derivatives, and prime-brokerage markets as suppliers of collateral. It highlights the incentives created by new regulations for different suppliers of collateral. Moreover, it argues the that central banks should be mindful of the effect of their actions on the ability of markets to intermediate collateral.
\end{abstract}

JEL Classification Numbers: G21; G28; F33; K22

Keywords: collateral velocity; securities lending; prime brokerage; OTC derivatives; repo Author's E-Mail Address: msingh@imf.org

${ }^{1}$ The paper benefits from discussions at the MCM seminar series, and from comments by Karl Habermeier and Luis Jácome, and also by the excellent research support by Zohair Alam. An earlier version of this paper appeared in The Journal of Financial Market Infrastructures, special edition on collateral, September 2016. A draft version was presented at the Atlanta Fed Conference, December 1-2, 2016. 


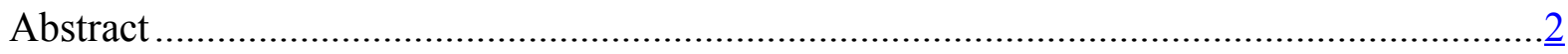

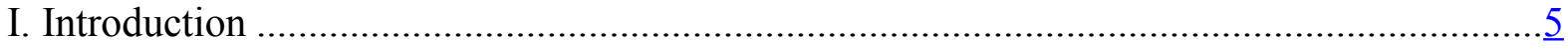

II. The Pledged Collateral Market ……………………...................................................

A. Pledged Collateral and the Discomfort with "Collateral Chains".............................. 6

B. Sources and Users of Pledged Collateral ..............................................................

III. Quantitative Easing (QE) and Regulations ................................................................ 2

IV. Evidence From SEC-Lending, Derivatives, and Prime-Brokerage Markets .......................16

A. Securities Lending.................................................................................

B. Derivative Markets Use of Collateral............................................................18

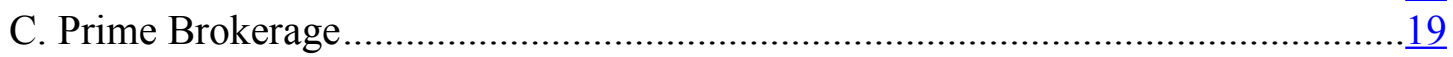

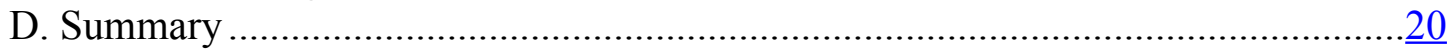

V. Collateral Reuse and Balance Sheet Constraints ...............................................................

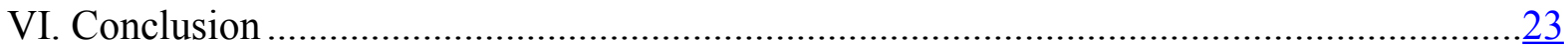

Tables

1. Sources of Pledged Collateral, Volume of Market, and Velocity........................................14

2. Securities Lending (2007-2015) ...............................................................................

3. Risk After Enforcement of Netting Agreements in OTC Derivatives .................................19

Figures

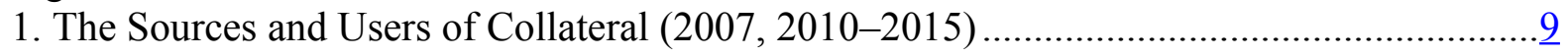

2. Bilateral Pledged Collateral Flows - via the Key Banks in this Market .............................11

3. The Collateral Map-QE and Regulatory Changes.........................................................13

4. Equity Long/Short Hedge Position ..............................................................................

5. By-Passing the Plumbing —An Example of a QE Unwind ..............................................23

Boxes

1. The 10-15 Banks at the Core of Global Financial Plumbing ............................................

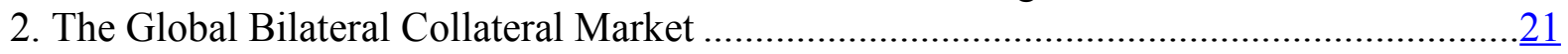

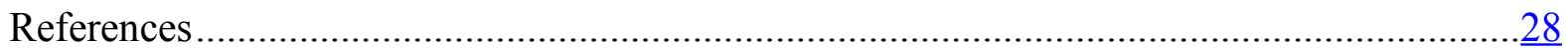

Annexes

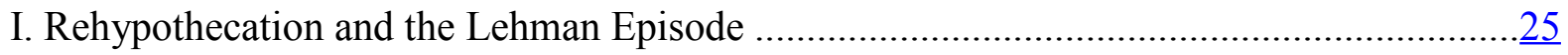

II. Methodology for Calculating the Velocity of Collateral ...................................................27 


\section{Glossary}

$\begin{array}{ll}\text { CCPs } & \text { Central Counterparties } \\ \text { CGFS } & \text { Committee on the Global Financial System } \\ \text { DTCC } & \text { Depositary Trust and Clearing Corporation } \\ \text { EU } & \text { European Union } \\ \text { FCD } & \text { Financial Collateral Directive } \\ \text { FDIC } & \text { Federal Deposit Insurance Corporation } \\ \text { FPCS } & \text { Financial Policy Committee Statement } \\ \text { FSB } & \text { Financial Stability Board } \\ \text { GC } & \text { General Collateral } \\ \text { GCF } & \text { General Collateral Finance } \\ \text { GMRA } & \text { Global Master Repo Agreement } \\ \text { GMSLA } & \text { Global Master Sec-Lending Agreement } \\ \text { G-SIFI } & \text { Globally Systematically Important Financial Institution } \\ \text { GSD } & \text { Government Securities Division } \\ \text { ISDA } & \text { International Swaps and Derivatives Association } \\ \text { LBIE } & \text { Lehman Brothers International Europe } \\ \text { PB } & \text { Prime Brokerage } \\ \text { QE } & \text { Quantitative Easing } \\ \text { RMA } & \text { Risk Management Association } \\ \text { RRP } & \text { Reverse-Repo Program } \\ \text { SEC } & \text { Securities Exchange Commission } \\ \text { TPR } & \text { Tri-party Repo }\end{array}$




\section{INTRODUCTION}

Collateral flows lie at the heart of any proper understanding of market liquidity, and hence of financial stability. The financial plumbing encompasses the biggest pipes that form the nexus between collateral and money; it can be seen as the interaction between nonbanks and banks in money markets and capital markets (the latter of which include securities lending, repos, derivatives, and prime brokerage). These activities are the nuts and bolts of financial plumbing.

For overall "lubrication" of its functioning, the financial system requires collateral or money for intraday debits and credits. The cross-border financial markets traditionally use "cash or cash equivalent" collateral (i.e., money or highly liquid fungible securities) in lieu of cash to settle accounts. Financial collateral does not have to be highly rated AAA/AA as long as the securities (which can be either debt or equity) are liquid, mark-to-market, and part of a legal cross-border master agreement, they can be used as "cash equivalent". In this way, collateral underpins a wide range of secured funding and hedging (primarily with OTC derivatives) transactions. Increasingly, collateral has a regulatory value as well as being cash-equivalent. Such financial collateral has not yet been quantified by regulators and is not (yet) part of official sector statistics, but is a key component of financial plumbing.

Perhaps no other market is so critical to the functioning of the financial system, and yet so poorly understood. In addition, as policymakers begin to rethink the traditional theories of money and lending, collateral flows are increasingly recognized to be just as important a driver of credit creation as money itself (Singh and Stella, 2012). Despite this, an appreciation of the importance of collateral flows is hampered by the limited understanding of the underlying economics and associated cross-border data. Much of this data are not compiled by national statistical data (such as the Flow of Funds in the U.S.) and thus not readily available in public databases, hence the need to "hand-pick" such cross-border flows that are mentioned in footnotes to annual reports of the large banks that have a footprint in this market.

There has been limited research in this area. The literature includes the work by Singh (2011) that develops the concept of "collateral velocity" and aligns pledged collateral with money from a liquidity perspective. Central banks (e.g., the Reserve Bank of Australia,2012; Bank of England 2013) have acknowledged these concepts in their speeches, noting that they are missing in standard textbooks. In a recent report on repo markets, the Committee on the Global Financial System (CGFS) has recognized the relevance of this line of research. Also recently, some central banks have included pledged collateral within the concept of international liquidity (ECB, 2016), and repo (New York Fed, 2016).

One objective of this paper is to complement the traditional understanding of money and money metrics with that of pledged collateral. Viewed together, both money and collateral provide a more comprehensive picture on how global liquidity should be considered. This is relevant since money (for example, the LM curve in the standard IS/LM framework) and associated money metrics do not incorporate the liquidity stemming from the pledged collateral. Furthermore, we highlight collateral flows not only from the perspective of the 
repo market (i.e., secured funding backed by collateral for a given tenor) and so the emphasize on other areas such as securities-lending, derivatives, and prime brokerage - that also move pledged collateral in the international markets. In the aftermath of quantitative easing $(\mathrm{QE})$ and certain new regulations, we explain how balance sheet constraints (i.e., private and public balance sheets) that impede the flow of pledged collateral.

The rest of the paper is organized as follows: Section II explains the concept of pledged collateral and how it leads to collateral chains. Furthermore, this section also highlights the key sources and users in the pledged collateral market. Section III shows the dual impact of QE and certain regulations (e.g., Basel, the Dodd Frank Act) on collateral. Section IV describes all avenues that bring in collateral to the market. Section $\mathrm{V}$ discusses the balance sheet constraints for the flow of collateral, and we conclude with some policy suggestions in Section VI.

\section{The Pledged Collateral Market}

This section provides the concepts and terminology used in this paper. In part A, concepts such as pledge, rehypothecation, collateral chains, and their relation to money are explained. Part B provides the sources of pledged collateral and the key players in the market that use (and reuse) pledged collateral.

\section{A. Pledged Collateral and the Discomfort with "Collateral Chains"}

The term "pledged for reuse" means that the collateral taker has the right to reuse it in their own name. Its practical effect is economically equivalent to title transfer (that is, a change in ownership) and is essential to the financial lubrication that makes collateral akin to cash-equivalent. In the pledged collateral market, contracts that embrace repo, securities lending, OTC derivatives (via a credit support annex), and customer margin loans may involve title transfer. Under a title transfer arrangement, the collateral provider transfers ownership of collateral to the collateral taker.

The latter acquires full title to the collateral received, and as its new owner, is completely free to utilize it. In return, the parties agree that once the collateral provider has discharged its financial obligation to the collateral taker, the collateral taker will return equivalent collateral to the collateral provider. Note that the obligation is to return equivalent collateral, that is to say securities of the same type and value terms, but not the original security. This point about equivalence is important. After the collateral has thus changed hands via title transfer and been reused by the collateral taker, it would not be obligatory on the part of the collateral taker to return exactly the same property initially received as collateral. A simplistic analogy is a physical US\$20 bill with serial number XYZ. If you provide that very bill as collateral to the collateral recipient, it does not matter if they give you back a different US\$20 bill—any US\$20 bill will do.

Although the terms "rehypothecation" and "pledged collateral that can be reused" are often employed interchangeably, each has a specific and slightly different meaning.

"Rehypothecation" means the use of financial collateral by a collateral taker as security for their own obligations to some third party (i.e., onward pledging). Reuse is broader in scope, encompassing not only repledging but also any use of the collateral compatible with ownership of the property (such as selling or lending it to a third party). Not all pledged collateral can be reused in this way due to legal restrictions. Rights of reuse are thus inherent 
in a title transfer financial collateral arrangements - because ownership of the property actually changes - whereas, under a pledge, the collateral taker takes a security interest only in the pledged assets and will enjoy rights of rehypothecation only if reuse is expressly granted in the pledge agreement. ${ }^{2}$ Market practice suggests that rehypothecation of assets has historically been a cheaper way of financing the prime business rather than turning to the repo market - and some of the recent regulations (such as leverage and liquidity ratios) are more beneficial to netting for prime brokerage (e.g., equity long/short positions), than repo. Within the U.S., rehypothecation rights are strictly limited—see Annex I.

Outside the U.S. (that is outside New York governed contracts), the prevalence of rehypothecation allows for a market clearing price for financial collateral (i.e., United Kingdom (U.K.) and continental Europe). Rights of reuse have a strong legal underpinning under the Financial Collateral Directive of the European Union (EU). The EU legal framework for financial collateral is flexible and can accommodate the preferences of prudent and risk averse clients and counterparties. Whether market participants strike bargains that offer them appropriate protection is a financial returns/risk choice, and regulators have allowed this asymmetry (i.e. U.S. has restriction on reuse but not EU) to exist under the new rules (e.g., Dodd Frank Act or Basel III). In most cases, U.K. broker-dealers operate subject to contractually agreed reuse limits.

Some views from academia (Brumm et al, 2017), and the financial stability groups (e.g., FSB, 2017) perceive "rehypothecation" to be potentially systemically dangerous, considering that it could facilitate leverage, possibly contributing to excessive leverage. However, ordinary banking practices are not entirely different. The "reuse" or rehypothecation of a security is somewhat analogous to the money creation that takes place in commercial banking through the process of accepting deposits and making loans (Singh and Stella, 2012). So why is it that a US $\$ 100$ deposit at a bank can be (partially) lent, but financial collateral that is marked-to-market at US $\$ 100$ dollars is restricted for reuse by policy? It is not clear that general concerns about potentially excess leverage should be addressed by preventing reuse of collateral. ${ }^{3}$ Moreover, at each step of a collateral flow, there are "haircuts" as shadow banks such as hedge funds are more adept at funding themselves via

\footnotetext{
${ }^{2}$ Under a pledged collateral agreement, the collateral taker, or the "pledgee" does not have automatic rights of reuse or rehypothecation in the pledge agreement unless such rights of reuse are expressly granted in the contract. The pledgee will not be able to seize or use that pledged collateral for their own purposes unless the "pledger" defaults on their obligation to the pledgee, triggering enforcement. However, in cases where a pledger, or collateral provider, grants a pledgee rights of rehypothecation over pledged collateral, and if the pledgee has exercised this right prior to insolvency, the pledger's legal rights are as if they had transferred title in the property to the pledgee. The pledger's legal remedies against an insolvent pledgee are, in practice, extremely limited.

${ }^{3}$ There may be frictions to collateral circulation if collateral chains break or unwind. Here it should be noted that pledged collateral is associated with title transfer. The typical pledged collateral documentation such as Global Master Repo Agreement (GMRA), Global Master Sec-Lending Agreements (GMSLA), and International Swaps and Derivatives Association (ISDA) documents requires return of "equivalent-not identical - collateral," thus there is little probability of default. This becomes important only in the event of liquidity constraints which takes us into the "fire sale" literature. Unless welfare analysis (i.e., costs/benefits) can show that the costs of frictions overshadow the funding and financial lubrication that underpins collateral reuse, it would be premature to constrain the reuse of collateral (which is already at a low of 1.8 - see Table 1.)
} 
collateral reuse than borrowing from commercial banks. Thus, the total haircuts (or cushion) in the shadow banking world is akin to capital, but remains 'shadowy' and not easy to quantify relative to Basel's eight percent minimum capital requirements. ${ }^{4}$

Moreover, since policies regarding collateral can affect overall financial conditions, they need to be considered when deciding other policies. In the aftermath of the global financial crisis, monetary policy has been very accommodative, with unusually low short-term interest rates, and central banks also using QE to try to rejuvenate credit creation. On the other hand, restricting collateral reuse is a policy that has a tightening impact (indeed, the collateral reuse rate has declined since 2007). The challenge is not only for policymakers to be aware of such effects of collateral policy, but to gauge their magnitude, and weigh their costs and benefits in a broader policy context. One step toward greater understanding of the macroeconomic relevance and impact of collateral would be to supplement traditional money metrics, such as M0, M1, and M2, with expanded metrics that integrate pledged collateral metrics.

\section{B. Sources and Users of Pledged Collateral}

The global market for pledged collateral is diagrammatically shown in Figure 1. The key sources of collateral providers are: (i) hedge funds; (ii) securities lenders that include pension funds, insurers, sovereign wealth funds; and (iii) central banks who often liaise via their custodians. This supply of "source" collateral is typically received by the central collateral desks of the dealer banks who have a global footprint in the pledged collateral market. ${ }^{5}$ This pledged collateral is received by the dealer banks against margin loans (e.g., in lieu of hedge funds prime brokerage agreements) reverse repos, securities borrowing (i.e., sec-lending from a pension fund's angle), and OTC derivatives positions. The users of collateral are primarily money market funds in lieu of cash looking for returns (i.e., the money markets remain the key money arteries of the financial plumbing). The discussion in this paper primarily focuses on the bilateral pledged collateral market where the elements of title transfer are embedded in the contract - this allows the collateral to move across jurisdictions without restrictions; thus this market is not confined to national boundaries. On the other hand, triparty collateral agreements restrict the collateral flows only within the triparty structure and hence are not included in Figure 1 (see Box 2 for further discussion).

\footnotetext{
${ }^{4}$ The capital ratio is the percentage of a bank's capital to its risk-weighted assets. Weights are defined by risksensitivity ratios whose calculation is dictated under the relevant Accord. Basel II requires that the total capital ratio must be no lower than eight percent. https://www.bis.org/publ/bcbs128b.pdf

${ }^{5}$ Major dealers active in the collateral industry include Goldman Sachs, Morgan Stanley, JPMorgan, Bank of America/Merrill, and Citibank in the U.S. In Europe and elsewhere, important collateral dealers are Deutsche Bank, UBS, Barclays, Credit Suisse, Société Générale, BNP Paribas, HSBC, Royal Bank of Scotland, and Nomura. Also, there is a de minimis supply (and demand) from commercial banks who need collateral for ratings/balance sheet reasons.
} 
Figure 1. The Sources and Users of Collateral (2007, 2010-2015)

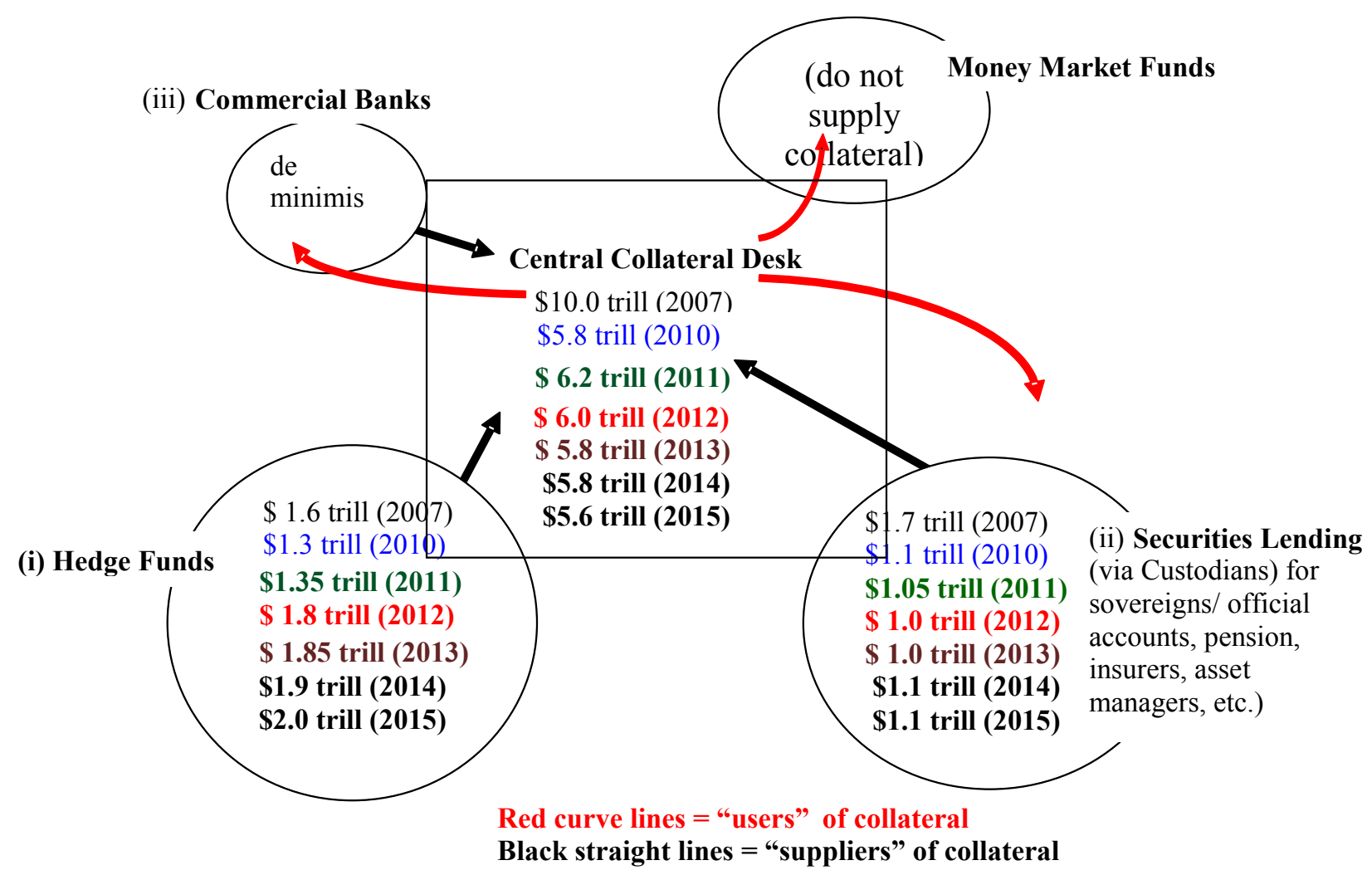

Source: Author's estimates.

\section{Quantitative Easing (QE) AND Regulations}

Expanded central bank balance sheets that silo sizeable holdings of U.S. Treasuries, U.K. Gilts, Japanese Government Bonds, German Bonds and other AAA eurozone collateral have placed central bankers in the midst of market plumbing. Unwinding of these balance sheets is not currently on the agenda (even where QE has stopped). As the plumbing entails the nexus (and pricing) of collateral in the market, any unwind of the balance sheet will have an impact on the price of collateral in the market's domain. Thus, signals from the collateral market (e.g., repo rates, or sec-lending rates, or prime brokerage funding rates) will become a function of the pace at which central banks unwind their balance sheets. This process likely will not be as simple as the previous purchases (e.g., the $\$ 85$ billion a month by the Fed under its QE program). Rates in the collateral market (that is, secured rates) need to be in sync with other short term rates (e.g., the Fed Funds rate); thus any unwind of the Fed balance sheet will need to ensure that secured and unsecured rates remain aligned.

Had QE not happened, then deposits within the banking system would perhaps have grown roughly in line with the economy's growth and/or household wealth. However, in the United States, data from June 2015 show that deposits with the Federal Deposit Insurance Corporation have doubled at the top 50 U.S. bank holding companies relative to June 2008 
levels. Moreover, Eurozone and Japan are continuing their QE, so deposits within their banking system will increase as ECB and Bank of Japan continue to print money.

Given the near double digit returns that G-SIFIs needs for their shareholders, some deposits are being pushed out to the official sector balance sheet; otherwise these deposits would be a drag for the banks and result in lower returns for their shareholders. In other words, the excess deposits (stemming from nonbank sales of collateral to the central banks), and the forthcoming regulations like the leverage ratio - that effectively requires banks to hold capital against deposits - are too "costly" for banks in the present near-zero rate environment (relative to the returns expected from shareholders), thus the reluctance by banks to take these deposits on their balance sheet. A typical bank's marginal return on these sizeable deposits is below their marginal return to their shareholders. Given the limited balance sheet space at the private sector banks, the demands for the official sector (i.e., central banks) balance sheet will remain important unless regulations are fine-tuned to allow for more bank/nonbank intermediation.

The core business of many of the large global dealer-banks (e.g., the SIFIs) is not deposit taking like a regional bank, or a "corner bank." Financial transactions, where collateral and money are interchangeable, are fundamental to the treasury of any SIFI that is the conduit for all global operations. In 2007, this global bilateral collateral market, where the global money and collateral exchange takes place, was US\$10 trillion in size (much of this was reflected in footnotes of balance sheets, which results in "data gaps" for regulatory oversight). Now it is much reduced, to well below $\$ 6$ trillion (note that the pledged collateral shown in Figure 2 is cross-border with no limits to reuse; this is not the case with the triparty structure in the U.S.- see Box 2). About half the pledged collateral comes from the hedge funds industry; and the other source of pledged collateral is from pension funds, insurers, central banks, sovereign wealth funds, and others (Singh, 2011; ESRB, 2014). 
Figure 2. Bilateral Pledged Collateral Flows-via the Key Banks in this Market

Pledged Collateral Received by U.S. Banks (2007-15)

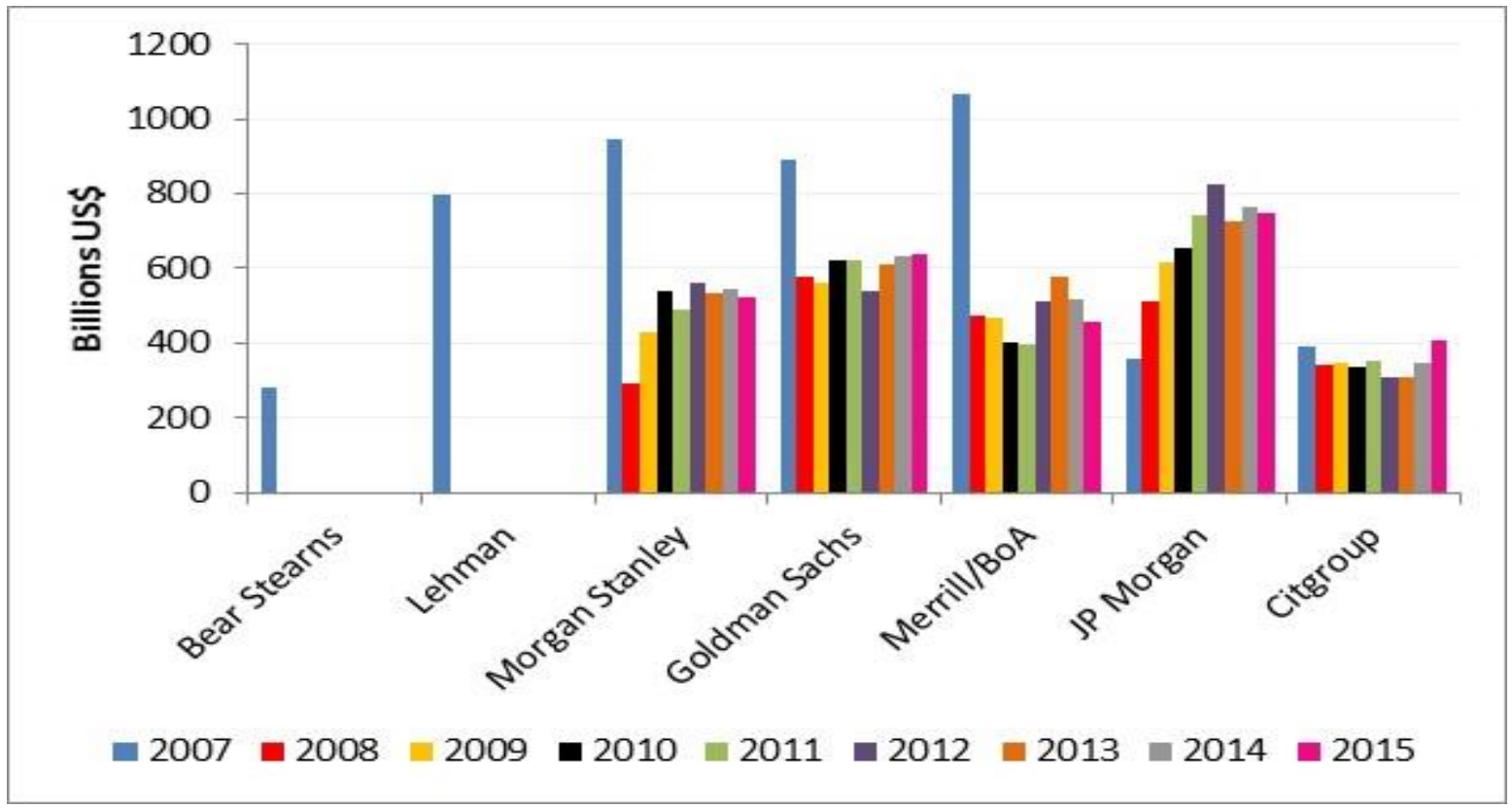

Pledged Collateral Received by European Banks, and Nomura (2007-15)

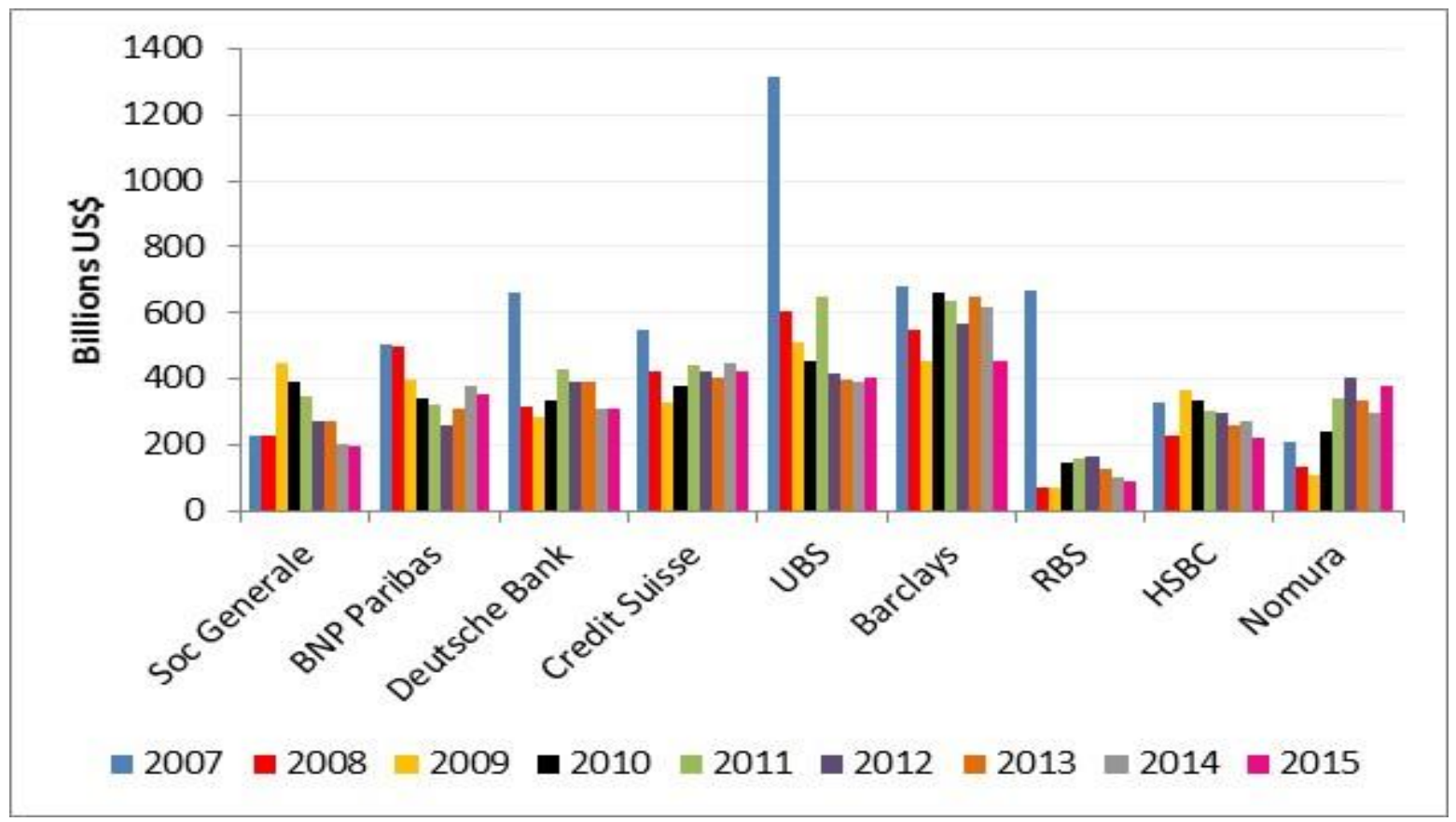

Source: Annual report of banks (e.g., 10K filings)—hand-picked data by author. 
Collateral with title transfer is pooled at the central collateral desks at large banks (the toptier G-SIFIs who have a global footprint). This collateral with title transfer, can come in to the banks via reverse repo, securities borrowing, OTC derivatives margin posting, or use of client assets under a prime-brokerage agreement. ${ }^{6} \mathrm{~A}$ recent study by the Office of Financial Research, U.S. Treasury (Baklanova et al, 2016) only provides an estimated range for the bilateral repo market of around \$1-2 trillion (and for the U.S. market only, not global). However, cross-border collateral reuse does not restrict the use of collateral to one jurisdiction (or a region) only; hence a collateral metric needs to be global.

The mechanics of QE and key regulatory changes have impacted the collateral market in a structural manner (see Figure 3). Due to QE (or similar actions that have led to large central bank balance sheets) since the global crisis, key central banks (e.g., the Fed and ECB) have now massive holdings of high quality collateral that cannot be reused; ${ }^{7}$ there is no timetable for unwind of their balance sheets (see blue boxes on left side of Figure 3 on magnitude of collateral absorbed). Furthermore, new regulations will entail additional demand of between \$2-4 trillion of high quality collateral, of which some will not be reusable (e.g., initial margin at CCPs, capital buffers etc.; CGFS 2013). Thus both QE and regulations constrain the flow of collateral by: (i) reducing balance sheet space (as deposits or excess reserves via QE now "sit" on bank balance sheets), and (ii) reducing the collateral reuse rate (or velocity), since good collateral assists in pricing (and thus moving) other pledged collateral in the market domain. On the other hand, there are positive developments on collateral by global custodians providing connectivity via "highways" and "liquidity hubs" - see purple boxes on the right side of Figure 3. Moreover, ongoing new debt issuance will provide some good collateral to the market - grey area at the bottom of Figure 3. However, as suggested by Figure 3, the incremental demand for collateral that is driven by regulations such as liquidity and leverage ratios is likely too far exceed the incremental supply from better collateral connectivity and new debt issuance. This shortage is now reflected in high quality collateral rates that are below zero percent (e.g., the Bunds) or, US Treasuries (around 50bps as the reverse repo program presently provides a floor at $50 \mathrm{bps}$ ).

\footnotetext{
${ }^{6}$ Thus any collateral metric should capture the typical documentation that underpins collateral use and reuse in contracts. The standard contracts are the GMSLA, GMRA, ISDA, and prime brokerage agreements.

Furthermore, pledged collateral from bilateral, securities-lending, prime brokerage, and OTC derivatives margin is hard to disentangle as it shows up bunched up in footnotes to balance sheets.

7 The balance sheet of the SNB (Swiss National Bank) has grown sizably, but not due to QE. The expansion occurred primarily while the SNB enforced a limit on the value of the Swiss franc relative to the euro (until Jan 2015), amid capital inflows during the Eurozone crisis.
} 


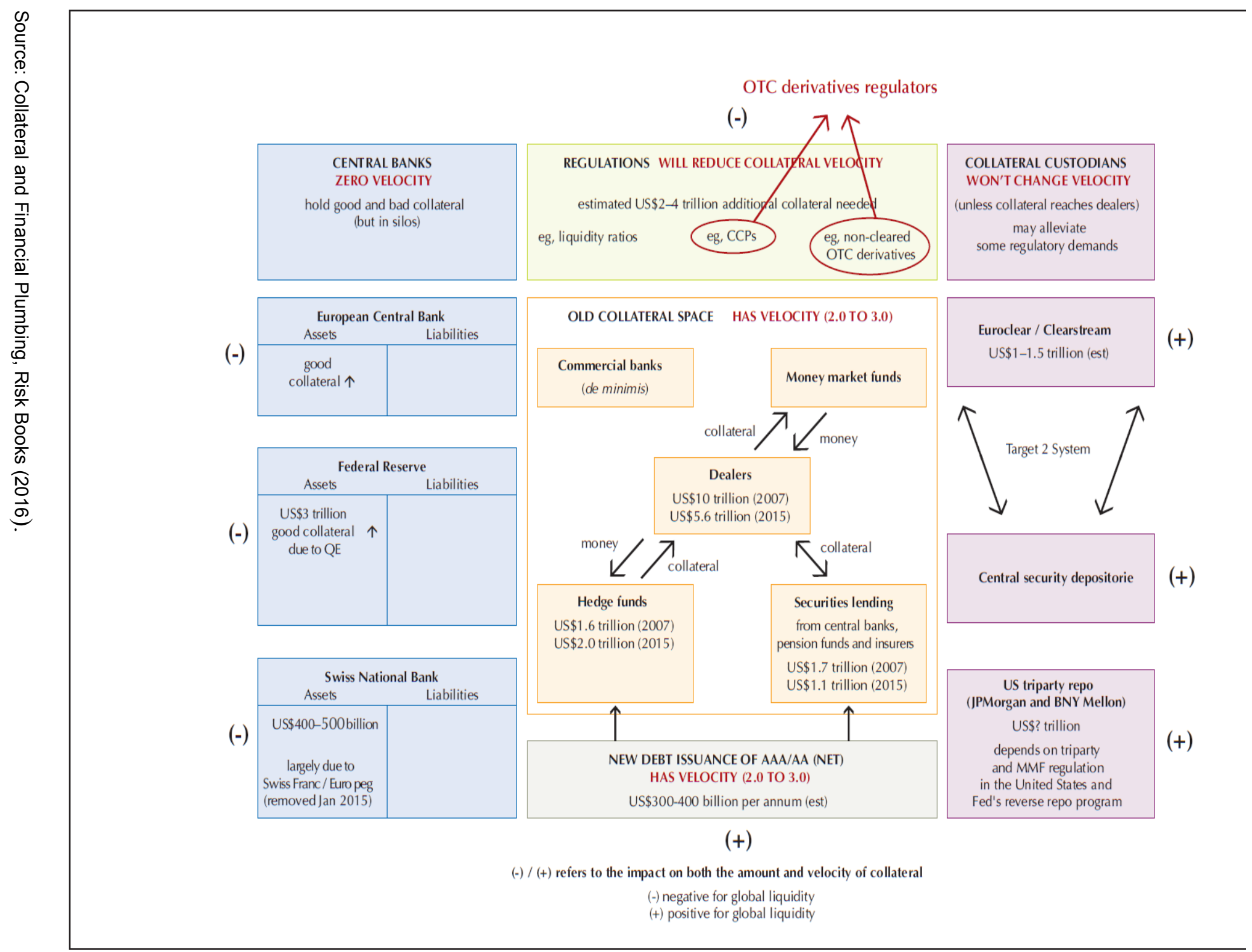

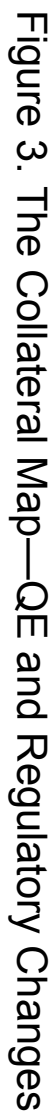


Table 1 provides a summary of estimates of the sources of collateral, the total volume received by the large banks, and the resultant "velocity." Collateral velocity is defined as the volume of secured transactions divided by the stock of source collateral-see Annex II. The velocity or the intensity with which collateral is used, is not intended as an exact metric but gives an idea of the length of the collateral chains in a given year. So we can infer that on average, the collateral chains were longer in 2007 than in 2015. A possible explanation is that counterparty risk before the Lehman event was minimal. In the aftermath of Lehman's demise, fewer trusted counterparties in the market owing to elevated counterparty risk led to stranded liquidity pools, incomplete markets, idle collateral, shorter collateral chains, missed trades, and deleveraging (Singh, 2012). As shown in Figure 2, since the crisis there has been some reshuffling of market share for the key banks active in this market. ${ }^{8}$ The collateral landscape also has changed further due to central banks' quantitative-easing policies and new regulations. Collateral reuse (or velocity) is now at about 1.8 relative to 3.0 before Lehman's demise.

\section{Table 1. Sources of Pledged Collateral, Volume of Market, and Velocity $(2007,2010-15)$ \\ (In trillions of U.S. dollars; Velocity in Units)}

\begin{tabular}{|c|c|c|c|c|c|}
\hline \multirow[b]{2}{*}{ Year } & \multicolumn{3}{|c|}{ Sources } & \multirow{2}{*}{$\begin{array}{l}\text { Volume of } \\
\text { Secured } \\
\text { Operations }\end{array}$} & \multirow{2}{*}{$\begin{array}{l}\text { Reuse Rate } \\
\text { (or Velocity) }\end{array}$} \\
\hline & Hedge Funds & Securities Lending & Total & & \\
\hline 2007 & 1.7 & 1.7 & 3.4 & 10.0 & 3.0 \\
\hline 2010 & 1.3 & 1.1 & 2.4 & 5.8 & 2.4 \\
\hline 2011 & 1.3 & 1.05 & 2.35 & 6.1 & 2.5 \\
\hline 2012 & 1.8 & 1.0 & 2.8 & 6.0 & 2.2 \\
\hline 2013 & 1.85 & 1.0 & 2.85 & 5.8 & 2.0 \\
\hline 2014 & 1.9 & 1.1 & 3.0 & 5.8 & 1.9 \\
\hline 2015 & 2.0 & 1.1 & 3.1 & 5.6 & 1.8 \\
\hline
\end{tabular}

Sources: RMA; IMF Working Paper, "Velocity of Pledged Collateral” (Singh, 2011).

\footnotetext{
${ }^{8}$ For example, JPMorgan absorbed Bear Stearns, and Nomura bought some business lines of Lehman; both have increased their market share. On the other hand, due to regulations, UBS has focused more on private wealth management and retracted from the pledged collateral business.
} 


\section{Box 1. The 10-15 Banks at the Core of Global Financial Plumbing}

Let the financial system that includes banks, hedge funds, pension funds, insurers, SWFs (sovereign wealth funds), etc. be represented by entities A to Z. Only a small number (say XYZ) have the capabilities to regularly move financial collateral across borders on a large scale. XYZ also happen to be the large 10-15 banks discussed earlier. The rest of the financial system from $\mathrm{A}$ to $\mathrm{W}$ that demand and supply collateral need to connect with each other via XYZ. Entry into this market is not prohibited but is extremely expensive and difficult, as it requires having a global footprint and global clients (and the acumen and sophistication to move and price liquid securities very quickly — in seconds sometimes). For example, a Chilean pension fund may want Indonesian bonds for six months, and W (for example, a hedge fund, or a securities lender in Hong Kong) may be holding these bonds and is willing to rent out to A for six months for a small fee. But $\mathrm{W}$ does not know there is demand from A. Only via XYZ can A connect to W. Since XYZ sits in the middle of the web, they have the ability to optimize in ways that give them an advantage. The Indonesian bonds may come into their possession because XYZ loaned $\mathrm{W}$ money, or because XYZ have a derivative with $\mathrm{W}$, or through a security lending agreement.

Such securities that need to move cross-borders under a "repo," or "security lending," or related transaction need to be legally perfected (and herein legal perfection entails rules such as title transfer and rehypothecation). Similarly, for OTC derivative margins, there is an International Swaps and Derivatives Association Master Agreement. For prime-brokerage/HF collateral, there is a similar master agreement that resonates easily between XYZ. Thus it is not easy for all real economy collateral (e.g., immovable assets, such as buildings) to be able to move across borders. This market for bilateral pledged collateral is the only true market that prices at mark-to-market all liquid securities (bonds + equities).

With the background of Figure 3, on the changes in the demand and supply of collateral, that argues that collateral may be in short supply — as reflected by repo rates - either of two things could happen to alter that situation:

(a) Velocity of collateral could come back - this is a task that only XYZ can handle in bulk if more good collateral is sourced through them. However, regulatory proposals such as leverage and liquidity ratio have resulted in balance sheet constraints for XYZ to do collateral transformation. So the velocity or re-user rate is unlikely to come back (see Table 2).

(b) Central banks could make balance sheet "space" to augment the balance sheets with XYZ; e.g., the Fed's reverse repo program since September 2013; augmented to almost \$2 trillion in December 2015. But that program does not release collateral to the market as it uses the triparty structure - so the Fed's counterparty gets ownership but not possession. Similarly, other central banks have tried to alleviate collateral concerns: for example, European Central Bank expanded its collateral framework (e.g., during the Eurozone crisis with subsidized haircuts relative to market prices such as those offered by LCH, U.K.). More recently, in the aftermath of ECB's QE since March 2015, its sec-lending program remains in its infancy. On the other hand, the Reserve Bank of Australia will not issue new debt to meet collateral demand, but will provide good collateral (or high quality liquid assets) at market price. 


\section{Evidence From SEC-Lending, Derivatives, AND Prime-Brokerage Markets}

Much has been written about repo markets shrinking but securities-lending, derivatives, and prime-brokerage are also key avenues for collateral flows and reuse (Bank of England 2013; ECB 2014; Baklanova et al, 2016). Thus the focus here is on these three avenues; repo (bilateral and triparty) is discussed succinctly in Box 2.

Since all the avenues for collateral flows need balance sheets to move, in the remainder of the paper we will focus on both the private and public sector balance sheets. Collateral does not flow in a vacuum and there may be constraints in the private balance sheets that in-turn is resulting in the official sector providing balance sheet space.

\section{A. Securities Lending}

While the large banks are unlikely to make room for the "high volume, low margin" securities lending business (due to leverage ratio constraints), regulators are of the opinion that non-banks such as the major custodians like BNY Mellon, Citi, State Street, Euroclear, and Clearstream will step in and provide "balance sheet space" to move collateral around. ${ }^{9}$ Assets held by custodians are not part of their balance sheet, only principal positions are on the balance sheet. However, indemnification requirement to clients requires upfront capital provision and this is not cost-effective (Singh, 2016). Prior to the 2008 Lehman event, dealers would oblige the custodians that would push out general collateral (e.g., IBM or Merck equities) along with "specials" that the dealers really wanted (and still do). In that era, the custodian would set a general collateral (GC) to 'specials' ratio as high as 5:1 or even 13:1 - there was less balance sheet constraint. For almost a decade now, there is no tying of $\mathrm{GC}$ to specials.

The asset-management complex, which includes pension, insurers, and official sector accounts such as sovereign wealth funds and central banks, is a rich source of collateral deposits. The securities they hold are continuously reinvested (via sec-lending) to maximize returns over their maturity tenor. In a repo there is an outright sale of the securities accompanied by a specific price and date at which the securities will be bought back.

On the other hand, securities lending transactions generally have no set end date and no set price. ${ }^{10}$ Borrowing in this market is generally done with a specified purpose and in many cases a legal purpose test is required. As such, securities lending markets are utilized to borrow specific securities whereas repo markets are generally non-security specific. In 2007,

\footnotetext{
${ }^{9}$ The custodians also have banks under the holding company (e.g. Euroclear Plc. owns Euroclear Bank SA/NV) similarly they may hold CSDs (central security depositories). We do not refer to the banking affiliates who have to comply with the banking regulations.

${ }^{10}$ It is standard practice to use title transfers in repo and securities lending activities. Securities lending transactions in the US are done via pledge, securities lending in Europe is title or "pure" transfer. Furthermore, with respect to legal rights, securities lending is effectively identical to repo although some securities lenders view that their client's rights are more secure than via a repo - due to indemnification of the borrower's potential failure to return securities or default. In Europe, the securities lending is done via the GMRA or the GMSLA. (In the US, the respective documents are MRA and the MSLA.) Also, OTC derivatives contracts under the ISDA use English law, where title transfer is part of the credit support agreements (CSAs).
} 
securities lending volumes were $\$ 1.7$ trillion. In recent years, despite collateral constraints, the volumes are flat at around \$1 trillion according to Risk Management Association (RMA) which unlike many other vendors, does not include reuse of securities in their data-see Table 2.

Initially, risk aversion due to counterparty risk immediately following the Lehman event had led many pension and insurance funds' official accounts not to let go of their collateral for incremental returns (i.e., supply was constrained). More recently, demand sided pressures such as the regulatory squeeze on the use of balance sheet and low returns on cash holdings have put a lid on this market. These figures are not rebounding as per end-2015 financial statements of banks. The RMA's data includes the largest custodians such as Bank of New York, State Street, and JPMorgan. ${ }^{11}$

Table 2. Securities Lending (2007-2015)

(In billions U.S. dollars)

\begin{tabular}{cccccccccc}
\hline & 2007 & $\mathbf{2 0 0 8}$ & $\mathbf{2 0 0 9}$ & $\mathbf{2 0 1 0}$ & $\mathbf{2 0 1 1}$ & $\mathbf{2 0 1 2}$ & $\mathbf{2 0 1 3}$ & $\mathbf{2 0 1 4}$ & $\mathbf{2 0 1 5}$ \\
\hline $\begin{array}{c}\text { Security Lending vs. } \\
\text { Cash Collateral }\end{array}$ & 1209 & 935 & 875 & 818 & 687 & 620 & 669 & 701 & 644 \\
$\begin{array}{c}\text { Securities Lending } \\
\text { vs. NonCash } \\
\text { Collateral }\end{array}$ & 486 & 251 & 270 & 301 & 370 & 378 & 338 & 425 & 454 \\
$\begin{array}{c}\text { Total Securities } \\
\text { Lending }\end{array}$ & 1,695 & $\mathbf{1 , 1 8 7}$ & $\mathbf{1 , 1 4 6}$ & $\mathbf{1 , 1 1 9}$ & $\mathbf{1 , 0 5 8}$ & $\mathbf{9 9 8}$ & $\mathbf{1 , 0 0 8}$ & $\mathbf{1 , 1 3 7}$ & $\mathbf{1 , 0 9 8}$ \\
\hline
\end{tabular}

Source: RMA.

Discussions with custodians suggest the future of the securities lending market in the new regulatory environments may depend on several factors discussed below:

- The noncash collateral market in the U.S. could take cues from the developments in Europe where term repo was normal, and sec-lending was against securities (and thus did not generate cash pools as in the U.S.).

\footnotetext{
${ }^{11}$ The decline in the first row of Table 2 requires some explanation. The U.S. regulatory rules that guide borrowers permit only cash and certain government securities (and investment grade corporates). Hence, the U.S. developed as a cash collateral business, where the lending agent lends client assets versus cash and then reinvests the cash according to the client's direction in very short-term reinvestments. Outside the U.S. (U.K., for instance), regulatory rules permit certain types of noncash collateral that are readily available (such as FTSE equities). In the aftermath of Lehman and the liquidity crisis, borrowers in the U.S. borrowed more hardto-borrow stocks (specials), and less general collateral; this explains the decline. Noncash collateral deals (i.e., collateral for collateral) effectively provide the lenders with a hard fee for the deal, and it does not give temporary cash to generate excess returns by creating a short-term, money-market book. The rebound in the second row reflects the desire to avoid cash pools that aside from earning near zero rates, had also led to legal issues that impact returns on client's collateral.
} 
- $\quad$ Equities can be increasingly mobilized and swapped with U.S. Treasuries, but certain regulations may need to change to facilitate this (e.g., Securities and Exchange Commission's rule 15c3 - see Annex I for details).

- $\quad$ Moreover, large holders of good collateral (e.g., U.S. Treasuries) in the Gulf region or some Asian countries cannot lend securities as some of the global dealer banks' rules prohibit netting of a sovereign client's transaction (due to their sovereign immunity privilege). This ambiguity of "netting" often results in the reluctance of the dealer banks to underwrite a sec-lending transaction with such clients, as sovereign immunity may provide another layer of protection during bankruptcy etc. ${ }^{12}$ Given the higher leverage ratio requirements for G-SIBs (especially in the U.S.), certain transactions thus do not make economic sense - if flows are "gross" they consume more balance sheet space than "net" flows. ${ }^{13}$

- While the supply side (i.e., central banks and sovereign wealth funds) may be eager to increase lending and the demand side (i.e., hedge funds) may be eager to increase borrowing, the intermediaries (i.e., large banks and agency lenders) will remain constrained by the regulations - for banks, by leverage and liquidity ratios; for agents, by single counterparty credit limits and conservative risk-based capital rules. For the market to grow back to pre-crisis size would probably need to involve a much larger participation by nonregulated institutions, and/or somehow connecting supply to demand without an intermediary. The FSB already has a working group to look at nonbank-to-nonbank collateral flows; if this picks ups momentum, this market will be a very different market than the one operates today. This market will be more opaque to understand (as it will be outside the traditional dealer banks), and where credit and duration management and intermediation would have to be assumed by a different group of players and potentially under a different set of rules.

\section{B. Derivative Markets Use of Collateral}

Unlike the "gross" flow of collateral in repo and sec-lending, in the OTC derivatives market, collateral flows (via variation margins) in line with the risk, and thus on a "net" basis. Banks do not provide collateral data to BIS's OTC derivatives survey; thus, the collateral issues in this market maybe large - about $\$ 3$ trillion by BIS estimates (Table 3), which if calibrated

\footnotetext{
${ }^{12}$ For transactions collateralized by cash, the collateral receiver gives out cash and has a receivable (asset), the collateral provider receives cash, and books a payable (liability). Essentially, the transaction is booked as a cash loan, or borrow, collateralized by the security lent (or repo-ed) from an accounting standpoint. Under U.S. GAAP if certain conditions are met (i.e., same counterparty, same explicit maturity date (not open), intent to net settle, master netting agreement in place, and legal right to offset in default), only then accounts receivables and payables can be netted down. Under Basel rules, if similar, but slightly more expansive requirements are met, only then the transactions are allowed to be netted. The legal right to offset in default has led to many prime brokers determining that certain counterparties, most specifically sovereign wealth funds and central banks, cannot be netted.

${ }^{13}$ Also, in the U.S. almost all the states allow netting; thus it is easier for large pension/insurers to sec-lend to the large domestic banks.
} 
further suggests that sizable flow of collateral (or cash) will move to the balance sheet(s) private or public. This may be arduous since much of the initial margins is not allowed to move and so will be "parked" somewhere on a balance sheet. Collateral velocity is much lower now than pre-Lehman times, and if adjusted for this metric (lower velocity implies less off balance sheet moves), then it is unclear if balance sheets have the space to accommodate the required flows: this may be especially difficult since much of initial margins will not be allowed for rehypothecation. However, regulators may create balance sheet space, e.g., by tweaking the leverage ratio (as acknowledged the Bank of England's Financial Policy Committee Statement minutes of July 2016). ${ }^{14}$ Cognizant of the dilemma and the regulatory nudge towards mandatory clearing of standard contracts at CCPs, these large institutions are now allowed to park client margins at some central banks (e.g., the Fed). This privileged access is not available for the Apple, Microsoft, or the Walmart treasurer who also have large cash to park somewhere in the financial system. As Table 3 shows, the likely shortfall in the OTC derivatives market, if addressed, may lead to sizable deposits at central banks directly by CCPs. This short circuits the market plumbing where money earns a return. Such ad hoc provision of balance sheet space impacts the money/collateral nexus and weakens the market forces that provided plumbing signals (e.g., collateral rates such as repo).

\section{Table 3. Risk After Enforcement of Netting Agreements in OTC Derivatives Market}

\begin{tabular}{|c|c|c|c|c|c|c|c|c|c|c|c|c|c|c|c|c|}
\hline & H22008 & H12009 & H22009 & H12010 & H22010 & H12011 & H22011 & H12012 & H22012 & 013 & H22013 & H12014 & H22014 & H12015 & H22015 & H12016 \\
\hline GRANTOTAL & 35,281 & 25,314 & 21,542 & 24,673 & 21,296 & 19,518 & 27,285 & 25,392 & 24,740 & 20,245 & 18825 & 17,438 & 20,880 & 15,313 & 14,498 & 20,701 \\
\hline A. Foreign exchangec contracts & 4,084 & 2,470 & 2,070 & 2,524 & 2,482 & 2,336 & 2,555 & 2,217 & 2,304 & 2,427 & 2,284 & 1,724 & 2,944 & 2,359 & 2,579 & 3,063 \\
\hline B. Interest rate contracts & 20,087 & 15,478 & 14,020 & 17,533 & 14,746 & 13,244 & 20,001 & 19,113 & 18,833 & 15,238 & 14,200 & 13,461 & 15,608 & 11,062 & 10,148 & 15,096 \\
\hline C. Equity-inked contracts & 1,112 & 879 & 708 & 706 & 648 & 708 & 679 & 645 & 605 & 692 & 700 & 678 & 615 & 606 & 495 & \\
\hline D. Commodity contracts & 955 & 682 & 545 & 457 & 526 & 471 & 487 & 390 & 358 & 384 & 264 & 269 & 317 & 237 & 297 & 12 \\
\hline E. Credit default swaps & 5,116 & 2,987 & 1,801 & 1,666 & 1,351 & 1,345 & 1,586 & 1,187 & 848 & 725 & 653 & 635 & 593 & 453 & 421 & 47 \\
\hline F. Unallocated & 3,927 & 2,817 & 2,398 & 1,788 & 1,543 & 1,414 & 1,977 & 1,840 & 1,792 & 779 & 724 & 671 & 803 & 596 & 558 & 1,473 \\
\hline GROSS CREDT EYPOSURE" & 50 & 3,744 & 3,521 & 3,778 & 3,480 & 2,971 & 3,912 & 3,668 & 3,626 & 3,784 & 3,033 & 2,826 & 3,358 & 2,870 & 2,853 & \\
\hline
\end{tabular}

Sources: BIS OTC Derivatives Semi-Annual Reports and various editions.

Note: Gross market values have been calculated as the sum of the total gross positive market value of contracts and the absolute value of the gross negative market value of contracts with non-reporting counterparties. Gross credit exposure is after taking into account legally enforceable bilateral netting arrangements.

\section{Prime Brokerage}

Some of the recent prime brokerage activity suggests that equity long/short positions (i.e., the delta bias) and associated netting is more balance sheet friendly than other collateral

\footnotetext{
${ }^{14}$ Markets can also rebound if the balance sheet space of intermediaries increases. This could happen if regulations are softened, or if central banks unwind their balance sheets and release deposits from the banking system to the economy.
} 
transactions - see Figure 4, which shows demand for equity funding relative to the standard equity market, the S\&P index. Intuitively, if there are more long positions relative to short positions, more collateral is released to the market. Hedge funds borrow from prime-brokers (mostly the 10-15 banks alluded to in Box 1) for equity long/short and event driven (e.g., credit/distressed, and merger arbitrage) strategies. Since the Lehman event, hedge funds have tended to finance roughly equally via prime-brokerage and repo strategies (adjusting for derivatives use/leverage within each strategy).

Figure 4. Equity Long/Short Hedge Position

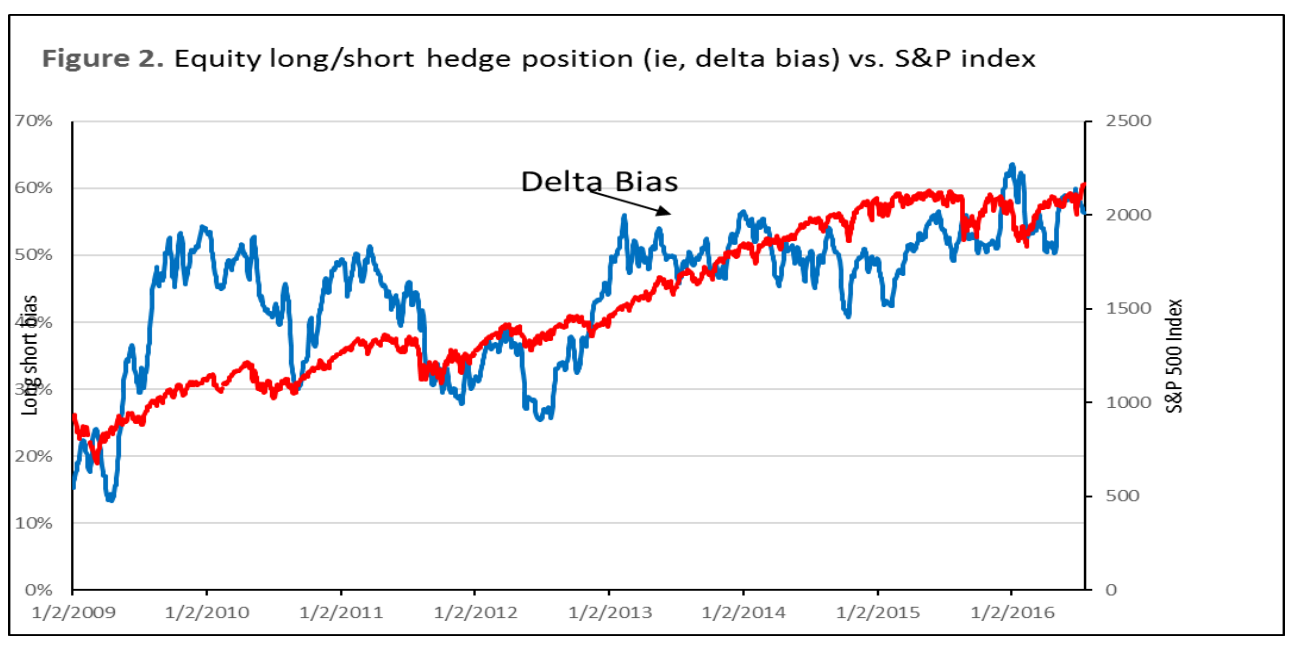

Source: Credit Suisse.

The accounting practices for prime brokerage (PB) lending and short covering offer more opportunities for balance sheet netting than do other contractual forms for the same market risk. In repo, each transfer of cash between counterparties (with limited exceptions) is separately accounted for as an asset or liability. In PB, the customer's net cash position after all security purchases and sales is all that goes directly on balance sheet. So if the PB can minimize on-balance sheet trades with non-PB customers that are required to meet the securities and cash needs of his PB customers (by rehypothecating one customer's long position to deliver against another's short, for instance) then he can minimize his reported balance sheet. Simply put, the accounting in PB follows the money, not the securities. The more the PB is able to optimize securities available against securities needed, the smaller the balance sheet required to provide the same services.

\section{Summary}

Succinctly put, the above sections A, B and C suggest a bias where private sector balance sheets will first accommodate net collateral flows and then gross collateral flows. Their objective now is to maximize profits per unit of balance sheet space. Thus, long-short equity via PB looks to be best placed from a balance sheet profit perspective-collateral flow are "net" and PB allows the flexibility of 140 percent use of clients collateral that is part of the PB business (see Annex I); then derivatives as collateral flows on "net" basis only (but does not have the extra 40 percent of clients collateral as an additional buffer as in PB transactions); then securities-lending but some of the biggest clients may not be accommodated as they are sovereign and their immunity may not allow for netting on dealer 
banks' balance sheet; hence these transactions may be on gross basis). The last in the queue is repo, as it is primarily for funding and not to augment returns - and regulations require repo to be on gross basis on the balance sheet.

\section{Box 2. The Global Bilateral Collateral Market (Relative to the U.S. Triparty Repo Market)}

This box summarizes the difference between the much researched tri-party "repo" market and the less researched bilateral collateral market; the latter includes collateral flows from not only bilateral repo but also securities lending, derivatives, and prime-brokerage. Collateral use and reuse in financial markets is large. Before the Lehman crash, the volume of funding via pledged collateral (including title transfer) was about US\$10 trillion, higher than the U.S. or EU broad measure of money, M2.

The U.S. bilateral repo market is a subset of the market for collateral: i.e., securities for possession and use (incidentally against cash). The bilateral repo market is sizable and although no official statistics exist, some recent work at central banks suggests this market to be at par or bigger than the tri-party repo (TPR) market (e.g., New York Fed estimates this market to be between \$1-2 trillion in the U.S. alone).

The TPR market in the U.S. is a market for funding: i.e., money for broker dealers/banks (incidentally collateralized by securities). The TPR market is currently estimated at US $\$ 1.6$ trillion from a peak of almost US $\$ 3$ trillion before the Lehman crisis. The TPR market provides banks with cash on a secured basis, with the collateral being posted to cash lenders (e.g., money market funds) through one of the two clearing banks-Bank of New York Mellon and JPMorgan (Copeland et al 2010).

Think of the bilateral repo market via the analogy for old clothing trade: Typically, merchants in developed countries shrink wrap old clothes in shipping container sized bundles (under pressure) and send the plastic wrapped block to poor countries. There, a clothing broker buys it, and resells it by weight to jobbers. So if the block weighs 500 pounds and is sold in 10 pound lots; suppose some 50 people gather around. But some people pay slightly more to be at the front of the crowd, and some pay slightly less to be at back. Then the jobber cuts open the bundle, which suddenly explodes; everyone gathered jumps for the best pieces.

Collateral desks are a bit like those jobbers. Big lots come in from hedge funds and security lenders, and the large bank's collateral desk paws through it, searching for gems. Those gems go out bilateral to customers willing to pay a premium. The remainders go to those in the back of the line (for example, tri-party repo). To the extent securities eligible for the TPR market have demand in the bilateral market, banks will generally use them first in the bilateral market as it offers better price.

Figure 2 above depicts the bilateral pledged collateral and does not count TPR related collateral as it is trapped within the TPR structure. The operational structure of the RRP facility puts practical restrictions on the reuse of collateral outside the Triparty system. Collateral can only be used in a Triparty repo liability. (So a firm that is a "dealer" in the Triparty system such as JPMorgan Chase or Bank of New York Mellon could have as an asset a Fed RRP and as a liability a Triparty repo with a customer.) Members of the Government Securities Division (GSD) of the Depository Trust and Clearing Corporation (DTCC) can reuse the collateral within the General Collateral Finance (GCF) Triparty system. The important point is that reuse of collateral can only end in a Triparty repo; it can have no other use outside this system.

\section{Collateral Reuse and Balance Sheet Constraints}

As central banks unwind their balance sheets in the future, they likely will be mindful to let the market have possession of securities, previously bought via QE, as collateral, since the 
reuse rate of these securities is outside their control (Potter, 2016). ${ }^{15}$ With a large balance sheet, the unwind will be over a significant period of time, and thus not over the short term. Furthermore, if central banks remain part of the plumbing and take money directly from nonbanks, the financial plumbing that relies on such money gets constricted as dealer banks do not receive the money flow; thus the dealer banks that connect the money pools and collateral pools will unwind such connections and thereby constricts the plumbing.

The recent experience of the U.S. Fed sheds some light on the operational aspects that are relevant. For example, after the "taper tantrum" of May 2013 highlighted market volatility concerns, the Fed accompanied its liftoff decision in December 2015 with a large reverserepo program (RRP) - a deft way of handling financial stability concerns stemming from losses and/or volatility on longer-tenor U.S. Treasuries. Large foreign repo pools at the Fed (i.e., deposits of foreign governments, central banks and international official institutions), foreign exchange (FX) swap lines with certain central banks, and deposit accounts for central counterparties (CCPs) at central banks, etc., also suggest an expanded role for central bank balance sheets that manage long-term rates. However, financial plumbing, where money and collateral interface, is a role that has historically always been associated with private-sector market participants (i.e., bank, nonbanks, custodians etc.,) and not with central banks whose mandate is about monetary policy and short-term rates. Market interest rates, both short and long term, have effectively been determined in the pledged collateral market, where banks and other financial institutions exchange collateral (such as bonds and equities) for money. This appears to have been-changed after QE such that central banks and private sector both provide market rate signals.

Figure 5 depicts the exchange of money (shown by green arrows) for collateral (shown by purple arrows) among the financial agents. As an example of a central bank balance sheet unwinding, the impact of the Fed's RRP is represented by the red coloring of some of the boxes. The red replaces part of the blue boxes that denote the market's bilateral plumbing components. Without the RRP, there would be no red color and all boxes would be blue. The market would do all the plumbing and would price the rate at which money and collateral are exchanged (typically via repo, securities lending, prime brokerage, and derivative activities).

\footnotetext{
${ }^{15}$ From Potter (2016): “One might also worry that money market rates might not move together as rates rise, meaning that, for example, a disconnect might emerge between secured and unsecured rates, or between overnight and term instruments. Either situation could result in impaired transmission of monetary policy into broad financial conditions."
} 
Figure 5: By-Passing the Plumbing—An Example of a QE Unwind

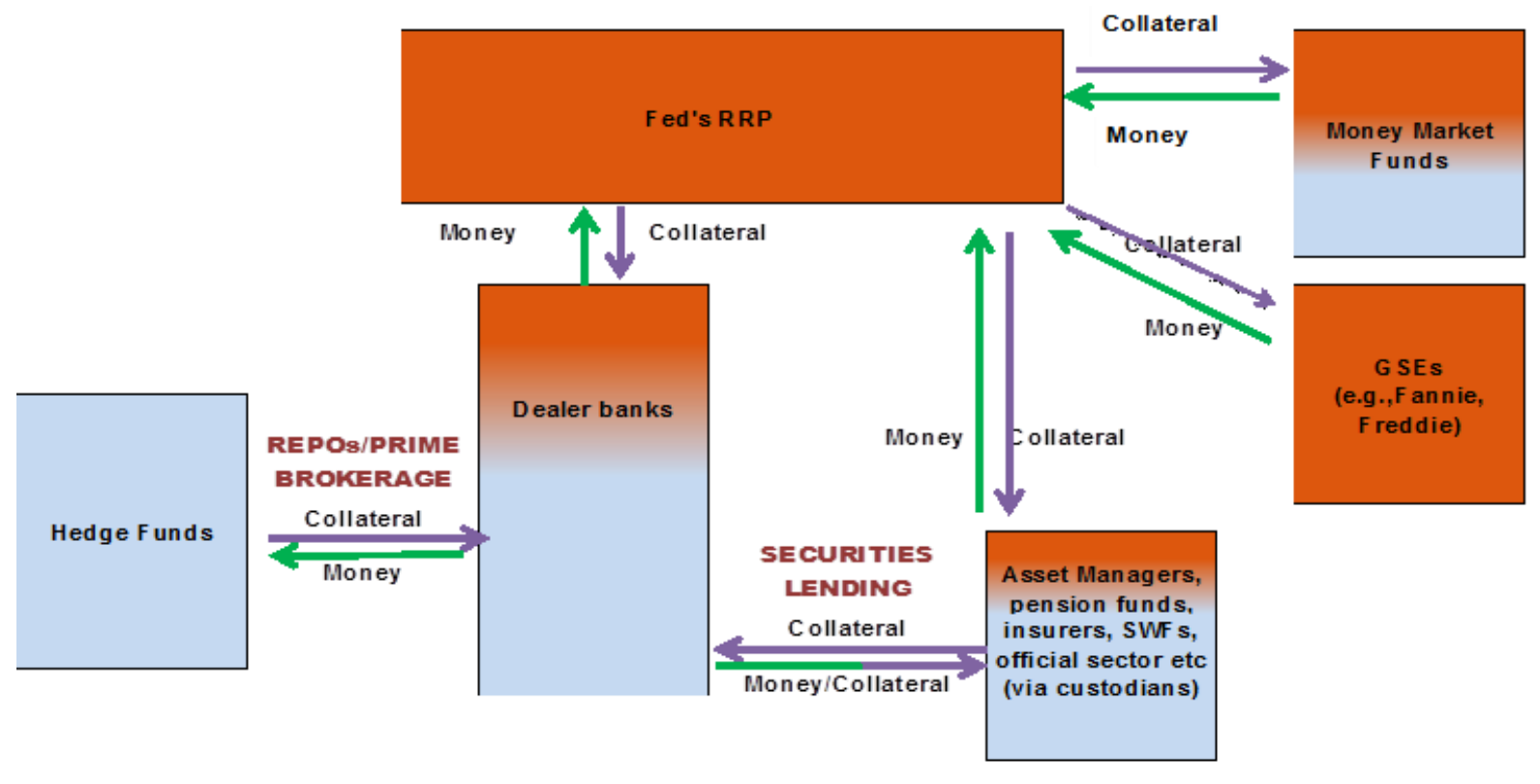

Source: Author's illustration.

The point is that the removing of collateral from the financial system and substituting collateral with excess reserves that QE created is likely to impact elements of the plumbing. and that monetary policy decision making will need to take account of such impact. The new regulations that constrain bank balance sheets further impede market plumbing. However, given the role of the banking system as conduits for the collateral flows, the plumbing will always be available for privileged clients (and transactions) of the banks, or custodian banks. Clients with transactions that are not balance sheet friendly will find the private dealer balance sheet space being rationed. The supply of balance sheet space for purposes of monetary policy (i.e., unsecured rates, inter-bank rates etc.), and associated market signals (i.e. secured rates such as repo or sec-lending etc.) — private or public - should in principle be transparent and driven by market forces without requiring ad hoc allocation by central banks. Going forward, monetary policy transmission could be improved if money flows do not short-circuit the plumbing; this would improve market signals since the volumes in the money/collateral exchange have already declined significantly (Figure 2).

\section{Conclusion}

If the proposed regulations are implemented as envisaged, there will likely be tension for access to the balance sheets of central banks and the large dealer banks. As alternatives to the likely dilemma of central banks providing balance sheet space, can nonbanks be providers of liquidity? Long-term asset managers (life insurance and pension funds) and sovereign wealth funds desire collateral that is of low volatility, but not necessarily highly liquid. These entities should be net providers of liquidity, either in the form of cash or liquid collateral. But, critically, their "need" for collateral is relatively stable (or, as providers of liquidity, they can dictate that counterparties take a fixed amount). In contrast, hedge funds, money market funds, and with certain new regulations, the dealer banks have a dramatically shifting need for collateral, and a large number of counterparties. Their needs are for liquid collateral. So a market for collateral-in theory_could work. Thus, the "principal" model (that embodies 
the banking industry) would shift to an "agency" model. Currently, it is not possible for nonbanks such as pension funds and insurers to directly deal with other nonbanks such as hedge funds since the latter are not rated; such regulatory constraints will keep the global banks at the center of financial plumbing (unless replaced by central banks).

In summary, it will be useful to: (i) recognize that in the new regulatory environment banks will maximize profits per unit of balance sheet space - thus "net" risk transfer (e.g., derivative margins, and certain prime brokerage positions) will be preferred by banks relative to "gross" flows (e.g., repos, and in some cases securities-lending); and (ii) seek to limit the central bank footprint in the plumbing by not providing balance sheet space in an ad hoc manner. Improved functioning of the collateral market will likely bring benefits in monetary policy transmission, money market signals, and market liquidity. 


\section{Annex I. Rehypothecation and the Lehman Episode}

Proposed regulations especially in Europe (e.g., EMIR or European Market Infrastructure Regulation, and Basel III) seem to be at odds with "title transfer". If I transfer title, then the recipient of collateral is able to use that asset in any way they deem fit. This is not compatible with regulations that treat the asset as "client property" and limit rehypothecation, or segregate for the client. In fact, insisting on segregation undermines the legal construction under which title was transferred. An important distinction is interpretation of the prefix "re" in "rehypothecation". In the U.S., this is normally done with a pledge with consent to reuse. So there is a clear distinction between pledged securities and sold securities. However, in Europe a repo is a contract of sale with a promise to repurchase at an agreed future date and price. Legally, if I sell securities, the resulting securities are no longer my securities; and, if these securities are then onward pledged, that is not a rehypothecation from my angle! However, is this economically different if I sell securities on the basis that you agree to sell me equivalent securities at some future time? The proposed Basel approach is on the lines that the existence of the promise to sell back means that the original sale is no longer a "pure" sale, and therefore caught by the rehypothecation restrictions.

Since the Lehman Brothers bankruptcy, there has been criticism in the U.S. that the U.K. has not had rigid quantitative regulatory caps on rehypothecation equivalent to those applicable to broker dealers regulated by the SEC in the United States (even though many U.K. brokers agree caps in contracts). Specifically, some feel that this asymmetry is akin to regulatory arbitrage and that the U.K. offers a unique forum for "unlimited rehypothecation".

But these criticisms overlook some counterarguments. First, as subsequent litigation revealed, the U.K. broker Lehman Brothers International Europe (LBIE) appeared to have broken the U.K. rules on client asset segregation. In certain cases, it appears that LBIE had not been properly segregating client property. Quantitative limits on reuse do not protect clients whose brokers do not follow the rules; thus rehypothecation rules are not to blame. Second, it could be argued that Lehman clients who had voluntarily agreed to give broad rights of reuse in their prime brokerage contracts essentially got what they bargained for when LBIE failed. Those clients (for the most part, professional and sophisticated counterparties) had misjudged the counterparty credit risk on Lehman, but they had not been cheated any more than an uninsured depositor is "cheated" by a failing bank. Third, the types of counterparties that go to London rather than Frankfurt or Paris do not so much for any unique features of U.K. law as EU law also does not restrict collateral use. ${ }^{16}$

In fact, the strong legal basis for title transfer financial collateral actually has its roots in English law, which also underpins the Financial Collateral Directive of the EU. Arguably, the

\footnotetext{
${ }^{16}$ A key reason why hedge funds may have previously opted for funding in Europe is that leverage is not capped as in the United States via the 140 percent rule under Rule 15c3-3. In the U.S., the SEC's Rule 15c3-3 prevents a broker dealer from using its customer's securities to finance its proprietary activities. Under this rule, the broker- dealer may use/rehypothecate an amount up to 140 percent of the customer's debit balance (i.e., borrowing from the broker dealer). As an example, assume a customer has US $\$ 500$ in pledged securities and a debit balance of US\$200, resulting in net equity of US\$300. The broker dealer can rehypothecate up to US $\$ 280$ of the client's assets (140 percent x US\$200). Created by the Securities Investor Protection Act (SIPA), the Securities Investor Protection Corporation (SIPC) is an important part of the overall system of investor protection in the United States. SIPC's focus is very specific: restoring securities (rather than cash) to investors with assets in the hands of bankrupt brokerage firms (e.g., Lehman).
} 
market is in London not necessarily because it offers unique arbitrage, but perhaps more importantly because U.K. courts are viewed with a long history of contractual adjudication and legal principles. 


\section{Annex II. Methodology for Calculating the Velocity of Collateral}

Our understanding is that there are 10-15 large banks active in collateral management globally. We may have missed a couple of banks but believe the calculations of velocity pick up over 90 percent of the pledged collateral that is received from primary sources such as hedge funds, pension funds and insurers, and official accounts.

We compare data between 2007 and 2015 to see how this market has changed from before Lehman's bankruptcy through the financial crisis, a period which straddles monetary policy experiments. As a starting point, we take the total collateral received by the banks as of end-2007 (almost US\$10 trillion), and compare it to the primary sources of collateral (the two primary source buckets identified in Figure 2, namely hedge funds and security lenders (on behalf of pension, insurers, official accounts, etc.) The ratio of the total collateral received in a given year to the stock of primary sources of collateral at end year is the average "velocity of collateral" due to the intermediation by the dealers.

$$
\text { Velocity of collateral }=\frac{\$ 10 \text { trillion }}{\$ 3.3 \text { trillion }}=\text { approx. } 3.0
$$

\section{Collateral sources as of end-2015:}

Similarly, for 2015, total collateral from primary sources that could be re-pledged by the large dealers from hedge funds was US\$2.0 trillion, plus US\$1.1 trillion via security lending operations of custodians on behalf of pension funds, insurers, and official sector accounts, for a total of US $\$ 3.1$ trillion. The total collateral received by the 10-15 large banks was US\$5.6 trillion as of end-2015 (still sharply lower than the US\$10 trillion peak as of end-2007)

$$
\text { Velocity of collateral }=\frac{\text { US\$5.6 trillion }}{\text { US\$3.1 trillion }}=\text { approx. } 1.8
$$




\section{References}

Baklanova, Viktoria, Cecilia Caglio, Marco Cipriani and Adam Copeland, 2016, "The U.S. Bilateral Repo Market: Lessons from a New Survey," Office of Financial Research, January.

Bank of England, 2013, The Future of Repo: ‘too much' or 'too little'? June.

Brumm, Johannes, Michael Grill, Felix Kubler, and Karl Schmedders, 2017, "Reuse of collateral: Leverage, Volatility and Welfare”, forthcoming working paper.

Committee on the Global Financial System (CGFS), 2013, “Asset Encumbrance, Financial Reform and the Demand for Collateral Assets", paper No 40, May.

report). ,2016, Study Group on Repo market functioning, November (interim

European Central Bank, 2014, Europe's Repo Market: improvements for collateral and liquidity management, July.

,2016, International Liquidity - presentation by Philipp Hartmann at the Conference of Charles Goodhart on "The Life of a Central Banker", October.

European Systemic Risk Board, 2014. An Analysis of the ESRB's First Data Collection on Securities Financing Transactions and Collateral (re)use, Occasional Paper No. 6, September.

Financial Stability Board, 2017, Re-hypothecation and collateral reuse: Potential financial stability issues, market evolution and regulatory approaches, January.

Gourinchas, Pierre-Olivier and Olivier Jeanne, 2012, “'Global Safe Assets,'” BIS Working Paper No. 399 (December).

New York Federal Reserve, 2016, A New Survey of the US Bilateral Repo Market, Staff Report No.758, January. (also cross-referenced as Baklanova et al, OFR paper)

Potter, Simon, (2016), Money Markets after Liftoff: Assessment to Date and the Road Ahead, New York Fed speech at Columbia University, February 22.

Reserve Bank of Australia, 2012, On Europe's Effects on Australian Financial Markets, Sydney, February 14 (by Assistant Governor Guy Debelle).

http://www.rba.gov.au/speeches/2012/sp-ag-140212.html

Singh, Manmohan, 2011, "Velocity of Pledged Collateral-Policy and Analysis," IMF Working Paper 11/256.

and Peter Stella, 2012, Vox article, "Central Bank reserve creation in the era of negative money multipliers", May. $\underline{\text { http://voxeu.org/article/central-bank-reserve-creation-era-negative-money-multipliers }}$ 
2015, Managing the Fed's Liftoff and Transmission of Monetary Policy, IMF Working Paper 15/202.

2016, Risk Books Collateral and Financial Plumbing. 